\title{
Implications of the Articulation Gap between Geography Learners in Secondary Schools and University
}

\author{
Khashane Stephen Malatji \\ Rachael Jesika Singh
}

\section{Abstract}

There is a concern in South Africa that most learners arrive at university underprepared. This is also a major concern for students who enroll for the BEd programme specialising in geography education. Due to the learners' articulation gap, they are unable to cope with the standard that is expected of them. Hence this study investigated the level of geography learners' preparedness when they arrive at university. The aim of the study was to investigate the challenges experienced by geography students in their first-year of study. The researchers used a qualitative approach grounded in phenomenology as the research design. Purposive sampling was used to select students who failed geography education in both semesters in their first-year of study, the academic year 2016. Two lecturers who teach geography in the first-year were sampled. The geography curriculum used in the secondary schools and university were also reviewed to determine the extent of alignment between the two. A thematic approach was used to analyse the data. The results of the study revealed that geography students enter university without proper preparation, and are therefore unable to cope with their first-year of study. The study further revealed that teachers who teach geography in secondary school are not sufficiently trained to teach geography, which results in their engaging in surface learning as opposed to deep learning. The study recommends that there be collaboration between secondary schools and universities to discuss the university's expectations with regard to learner preparedness. Moreover, geography teachers should be trained on an on-going basis in order for them to keep up with current trends in the area of geography education. 
Keywords: Geography education, teaching strategy, deep learning, disadvantaged schools.

\section{Background and Introduction}

Geography education is the study of the Earth, its natural and physical environments, human activities and social changes. It also involves the study of how these elements interact and the resulting effects, from a local to a global scale. Among the many skills involved are the use of mapping and fieldwork. When taught well geography makes a fundamental contribution to the education of young people, promoting the development of citizenship. Ensuring the quality of geography education is consequently of great significance to policy makers and education leaders, both here and internationally (Jucu 2012: 11). Teachers in the secondary schools of Mankweng Circuit appear to be experiencing challenges when it comes to teaching geography and preparing students for tertiary education. There is poor alignment between the teaching of geography in the basic education phase and at the level of higher education, which results in a wide articulation gap among students who attempt to cope with tertiary education.

Researchers such as Wilton (2012: 19) and Sidiropoulos (2016: 10) have conducted studies on the teaching of geography and the difficulties experienced by teachers in the basic education phase in South Africa, while Spaull (2016: 14) and Heywood (2000: 13) have investigated geography teaching in higher education. The curriculum used in South African schools is prescribed by the Department of Basic Education. However, at the higher education level, each university in South Africa decides what they want to include in their curriculum. Researchers such as Blonde (2014: 18) argue that the content of the curriculum in the universities may affect the quality of teachers they produce and ultimately the quality of education in South Africa. In this study, the researchers observed that some of the universities design their Geography curriculum without consulting either the school curriculum or geography teachers in the basic education system. The literature shows that there is a disjunction between basic education and the universities. We refer to this disjunction as an articulation gap, which comes about as a result of poor alignment and the lack of a working relationship between education at school and university level. Jucu (2012: 17) argues that universities that participate in 
teacher training are supposed to adopt the basic education curriculum to ensure consistency and alignment between the two. In geography teaching in higher education, the baseline understanding of the student is fundamental to their achieving a pass mark.

The foundational understanding of geography lies with the learners, what they bring to the class, how they respond to information and what they gain from their learning. Other dimensions of effective learning focus on the 'how' in translating the findings and understandings from research about learners into effective teaching, curriculum, resources and pedagogy (Psifidou 2009: 11). It appears that those who teach geography in primary and secondary schools and in further and higher education need to be supported by research intelligence in at least six priority areas, in order to:

- Clarify the purposes and goals of geography education, no matter how the geography curriculum is expressed locally;

- Refine curriculum, pedagogic and assessment practices used in the teaching and learning of geography;

- Deepen collective understanding of learning progressions in geography;

- Improve ways in which high quality materials and resources for geography teaching and learning can be developed and provided;

- Develop understanding of learners' geographical knowledge and experience, including their misconceptions, to enhance the teaching and learning of geography;

- Improve the teacher education of geography educators, linking innovative teaching practices to empirical research in geography education (Martins 2012: 13).

Reflecting on these priority areas, teachers should consider the kind of learners they have in the classroom. Learners include all the children, youth and adults engaged in learning in formal institutions and informal settings. This dimension of research in geography education concerns such aspects as how learners gain and develop their geographical experiences and their understanding of geography during their lives from their earliest years (McLafferty 2007: 16). It 
can be influenced by theories of learning. It encompasses learning informally and in educational settings, learners' motivations, their knowledge and misunderstandings, and their views about their experiences of geography education.

\section{Teaching Styles in Geography}

The term 'teaching style' is used to characterise the way in which geography is taught. Clearly this has an important influence on the educational experience of pupils in geography because it affects how they learn geography. In the context of this study, the way students were taught at school affected their learning in the institution of higher learning they were attending. Researchers such as Swanson (2013: 13) argue that a teacher's teaching style is determined by their 'behaviour' (their demeanour and the way in which they relate to pupils) and the strategy that they choose in order to bring about the intended learning outcomes. Some teachers feel that certain teaching styles and strategies are more appropriate for them because they suit their personality and reflect their philosophy of teaching. In the context of basic education, teachers are often compelled to engage in surface learning because learners are unable to engage critically with the syllabus. However, it is now generally accepted that teachers need to develop a repertoire of different styles and strategies (Meristo \& Eistenschmidt 2014: 18). The reason for this is because they need to consider the characteristics and needs of their pupils (their attitudes, abilities and preferred ways of learning) and the intended learning outcomes, as well as their own preferred ways of teaching.

Mashele (2016: 10) is of the view that geography teachers draw upon their own body of pedagogic knowledge about how they teach and how pupils learn. Teachers' personal qualities and their approach to classroom management influence the way that they teach. In the context of higher education, the nature of the learning environment that lecturers work in (classroom appearance and layout), the size of the class and the availability of appropriate learning resources also have a significant influence on the decisions that they make about their teaching (Pichana 2017: 14). Johnson (2017: 11) is also of the view that many of the terms that are used to describe different ways of teaching are not always helpful. Mutshaeni (2015) agrees that terms such as didactic, teacher-directed, whole-class, practical and experiential provide what are at best only general descriptions. When used to describe 
teaching styles, terms such as 'progressive' and 'traditional' are value-laden and stereotypical extremes. For example, one might assume that 'progressive' teaching is necessarily enquiry-based, child-centred, concerned with problemsolving, and therefore represents a forward-looking and effective approach to teaching geography.

Traditional teaching may be seen as being old-fashioned, autocratic, didactic and lacking creative opportunities, or as being reliable and effective at maintaining academic standards. Opinions about the relative strengths and weaknesses of different styles of teaching vary and such descriptions only give a partial view of how a teacher may be teaching (Harris \& Brown 2013: 19).

\section{The Role of Literacy in Learning Geography}

Literacy has a significant role in teaching and learning in higher education. When learners exit basic education to enrol at university they are expected to move from surface learning to deep learning (Johnson 2017: 17). In higher education more space is created for criticality, reflection and praxis. That means that students should be able to think critically, reflect on the topic taught and what it means to them, and apply what they have learned in class practically. Sikhwari and Malatji (2017: 19) are of the view that problem solving is a critical teaching strategy appropriate in higher education. In the context of geography teaching, deep learning is also necessary in order to produce teachers who are critical. There is a need constantly to encourage learners to be critical during their tertiary education. Researchers such as Mashele (2016:15) argue that most students in South Africa enter universities underprepared. The Blue Paper on Higher Education (2000: 33) recommended that universities should broaden access for students and at the same time support them to cope with their studies. Such a call has resulted in overcrowding in higher education, requiring lecturers to use teaching strategies such as co-operative learning, which demands that students take responsibility for their learning.

This results in an articulation gap, where students who are used to a teacher-centred approach now find themselves in charge of their learning and the need to express their ideas sometimes in a language that is not their mother tongue. As a result they find it difficult to adapt to and cope with learning in higher education. 


\section{How Geography Educators Learn in their Professional Work}

Geography educators are generally employed in schools, universities, field study centres and government ministries. These different contexts reflect different work-place settings in which learning on the job is done. In the context of this study, new university students bring with them the knowledge and experience gained from their basic education, which affects the way they learn. Researchers such as Malatji and Wadesango (2014: 5) are of the view that baseline information plays a significant role in how students learn in the higher education context. While the demands on the educators vary there will be a reasonable amount of common ground in the ways that they learn. What is likely to differ among subjects are the types of examples of learning, because they will relate directly to the different professional contexts in which these educators operate.

\section{Learning through Formal Training}

All geography learners will have experienced formal training prior to beginning their university education. However, their experience at school has repercussions on the way they learn. Poor alignment between basic education and higher education results in an articulation gap that affects the way student learn. Basic education teachers are educated and trained to become geography teachers. Many of these educators accept the challenge to upgrade their qualifications by undertaking further formal training, and have received higher university credentials. However, the nature of the learners in schools forces them to approach teaching in a particular way, which may deviate from the way they were trained. Researchers such as Mangena (2017: 9) argue that most of the institutions of higher learning that are involved in teacher training adopt a learner-centred approach as the model for training their teachers. However, this approach has been adopted without consultation with schools in the basic education domain, which results in what we have called the articulation gap.

\section{Brief Description of Kolb's (1974) Learning Style in the Context of Higher Education}

Kolb (1974: 4) views learning as an integrated process with each stage being mutually supportive of and feeding into the next stage. It is possible to enter 
the cycle at any stage and follow it through its logical sequence. In the context of geography teaching, the common practice is to start with theory before practice. However, effective learning only occurs when a learner is able to execute all stages of the model. Therefore, no one stage of the cycle is an effective learning procedure on its own. Kolb explains that different people naturally prefer a certain single different learning style. In the context of the secondary schools and university under study, there was a clear disjuncture that the university was not addressing, with the result that geography students were failing to cope with their first year of study.

Various factors influence a person's preferred style. For example, social environment, educational experiences, or the basic cognitive structure of the individual. Kolb models these variables in the figure below.

\section{Figure: Kolb's Learning Style}

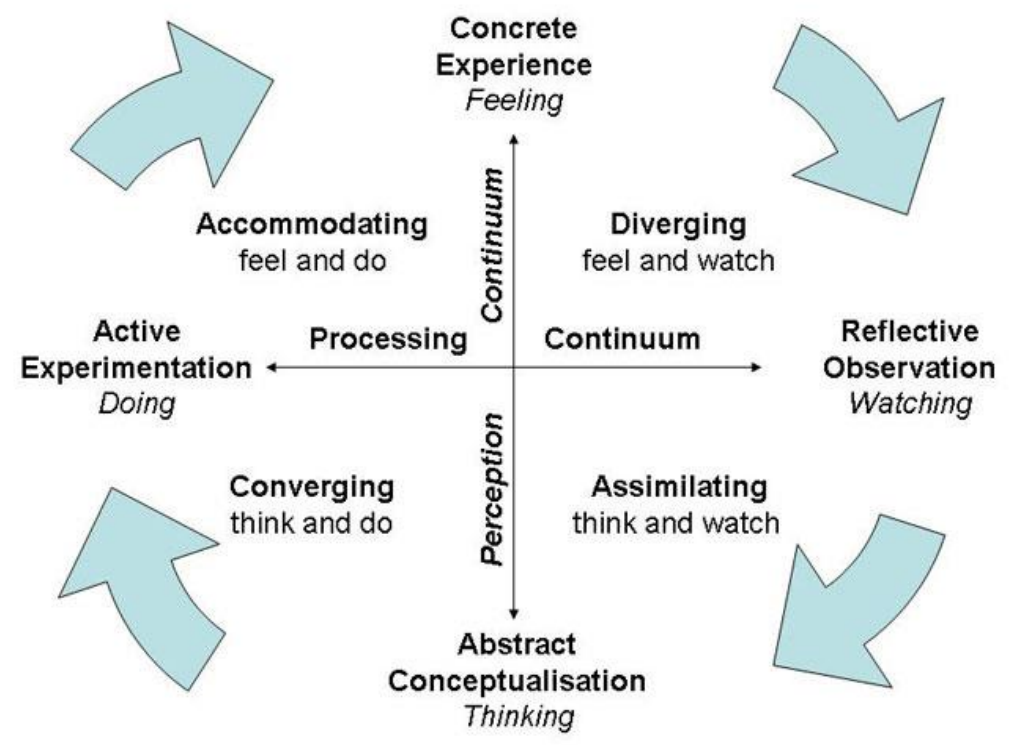


Kolb believes that we cannot perform both the variables on a single axis at the same time (e.g. think and feel). Our learning style is a product of choices among these variables. In the context of geography education, teaching and learning is centered on thinking and feeling. Students are encouraged to think critically and give their view on how they feel about certain issues. It is often easier to see the construction of Kolb's learning styles in terms of a two-bytwo matrix. Each learning style represents a combination of two preferred styles. The diagram also highlights Kolb's terminology for the four learning styles applicable to geography education: diverging, assimilating, converging, and accommodating.

\section{Application of Kolb's Theory in the Context of Higher Learning \\ Diverging (Feeling and Watching - CE/RO)}

Students are able to look at things from different perspectives. They are sensitive and they prefer to watch rather than do, tending to gather information and use their imagination to solve problems. They are best at viewing concrete situations from several different viewpoints. Kolb called this style 'diverging' because these people perform better in situations that require idea generation, for example, brainstorming. People with a diverging learning style have broad cultural interests and like to gather information. They are interested in people, tend to be imaginative and emotional, and tend to be strong in the arts. People with the diverging style prefer to work in groups, to listen with an open mind and to receive personal feedback. In the context of higher learning (geography teaching in particular), some of the active teaching strategies are small group teaching, cooperative learning and whole class discussion. Such strategies allow students to observe the learning process and give their input on how they feel and understand issues. In some disciplines students are taken on fieldwork outings for observation. Such practices as presented by Kolb accommodate students' different views and promote learning in a cooperative manner. In the context of this study, learners in the secondary schools of Mankweng Circuit are not exposed to field trips where they can relate to what they have learned in class, which creates problems when they join university in their first year of study. 


\section{Assimilating (Watching and Thinking - AC/RO)}

The assimilating learning preference is for a concise, logical approach. Ideas and concepts are more important than people. These people require good, clear explanations rather than practical opportunities. In the context of geography education, students should be introduced to some key concepts that will assist them to cope with their first year of study at university. Introducing students to key concepts would ultimately assist them to excel at understanding wideranging information and organising it in a clear logical format. People with an assimilating learning style are less focused on people and more interested in ideas and abstract concepts. People with this style are more attracted to logically sound theories than approaches based on practical value. This learning style is important for effectiveness in geography education. In the institution of higher learning, students with this learning style prefer reading, lectures, exploring analytical models, and having time to think things through.

\section{Converging (Doing and Thinking - AC/AE)}

People with a converging learning style can solve problems and will use their learning to find solutions to practical issues. They prefer technical tasks, and are less concerned with people and interpersonal aspects. People with a converging learning style are best at finding practical uses for ideas and theories. They can solve problems and make decisions by finding solutions to questions and problems. In the context of the institution of higher learning, research is one of the core businesses of the university. As proposed by Kolb, researching and finding solutions to existing problems is important for geography education. People with a converging learning style are more attracted to technical tasks and problems than social or interpersonal issues. A converging learning style enables specialist and technology abilities. People with a converging style like to experiment with new ideas, to simulate, and to work with practical applications.

\section{Accommodating (Doing and Feeling - CE/AE)}

The accommodating learning style is 'hands-on' and relies on intuition rather than logic. These people use other people's analysis, and prefer to take a practical, experiential approach. They are attracted to new challenges and experiences, and to carrying out plans. They commonly act on 'gut instinct' 
rather than logical analysis. People with an accommodating learning style tend to rely on others for information rather than carry out their own analysis. This learning style is prevalent within the general population. In the context of higher learning, the existing theories and literatures are discussed and scrutinised in order to come up with new theories. This kind of learning style requires people who think critically and are able to analyse. Therefore, accommodating learning styles become very important for teaching and learning to take place in geography education.

\section{Methodology}

The research approach adopted for this study was qualitative. The purpose of qualitative research is to develop an understanding of individuals and events in their natural state, taking into account the relevant context (Leedy 2001: 6). Qualitative research is aimed at gaining a deep understanding of a specific organisation or event, rather than a surface description of a large sample of a population. It aims to provide an explicit rendering of the structure, order, and broad patterns found among a group of participants. In qualitative research, the interpretation of data is achieved by means of set criteria in order to determine the depth or quality of the understanding of findings (Leedy 2001: 33). Procedures are not strictly formalised, the scope is more likely to be undefined, and a more philosophical mode is adopted (De Vos, Strydom \& Delport 2013: 23). The data was gathered through the investigation of small groups. The participants consisted of first-year geography students who failed Geography in the 2016 academic year, grade 12 geography students, and lecturers teaching the first-year geography class.

\section{Research Design}

The research design of this study is phenomenological. Cresswell (2007: 16) regards a phenomenological study as one that describes the meaning of the lived experiences of a phenomenon or concept for several individuals. In the context of this study, the experiences of geography teachers, learners, lecturers and students of the articulation gap between grade 12 and university geography education was investigated in order to determine the implication of this gap for first-year students' learning. The phenomenological approach aims to describe 
what the life world consists of, or more specifically, what concepts and structures of experience give form and meaning to it (Scharam 2006: 23). The researchers, using a phenomenological framework, strove to describe the phenomenon as accurately as possible, refraining from assumptions and remaining true to the facts (Thomas 2004: 11).

The present study aimed to understand the implications of the articulation gap between secondary schooling and university geography education for first year-students who intend to major in geography in their teaching qualification. The product of the research is a careful description of the conscious everyday experiences and social actions of subjects. Everyday experience, in this study, refers to actual secondary or university experiences in studying geography. In order to accomplish this, the researchers must extract meaning by making sense of the data provided. Researchers should also be able to distance themselves from their judgements and preconceptions about the nature and essence of experiences and events in their everyday world (Schram 2006: 16).

\section{Research Questions}

- What is the articulation gap between geography education in secondary schools and university?

- What are the experiences of geography first year students?

- What are the views of lecturers about the preparedness of first year geography students?

\section{Results}

The researchers investigated the articulation gap between geography education in secondary schools and university. Both the secondary school and university curriculum were reviewed to determine the extent of any constructive alignment (Biggs 2000: 11). Geography education students are trained and prepared to become teachers in the subject, so what students learn at university should be aligned with what is taught in schools in order for them to become competent geography teachers. When reviewing both the secondary and university curriculum the following themes emerged: 


\section{Poor Constructive Alignment between Secondary and University Education}

The geography education curriculum was supposed to be aligned with what is taught in schools in order to make the transition from school to university easier for students. In this study it was found that in some parts of the curriculum there is no connection between the two, and this affected students' learning. In the university curriculum reviewed it was found that a section called Geographical Information Systems (GIS) was not taught well in secondary schools, where it was given only the most basic of introductions (Dube 2012: 08). Kolb (1984: 11) argues that people with a converging learning style can solve problems and use their learning to find solutions to practical issues. In this study student teachers are training to become geography teachers. Therefore, they should be in a position to solve geographical problems and be able to operate effectively as geography teachers, bridging the articulation gap that exists between school and university teaching. Researchers such as Jucu (2012: 13) argue that the issue of surface learning affects learners in schools and ultimately our graduates at universities. Moreover, students encounter some content for the first time. With the academic freedom that universities enjoy, they are able to determine their curriculum content. Poor consultation between universities and secondary schools on curriculum development has resulted in these articulation gaps that affect students' learning.

\section{Moving away from Surface Learning to a Deep Learning Approach}

For the entire duration of students' secondary education, they are engaged in surface learning as opposed to deep learning - which, according to Kolb's (1974: 6) theory, is described as the assimilating learning style, in terms of which people consider ideas and concepts as more important. However, when students arrive at university they are expected to move away from surface learning to deep learning. Students in secondary schools are regarded as having no prior knowledge of the subject and are provided with all the information by their teachers, with the result that when they arrive at university and are expected to take ownership of their learning they are unable to do so. Spaull (2016: 12) argues that students of the 21st century should be encouraged to be independent and to take ownership of their learning. The study has revealed 
that most of the students lacked the confidence to express their views during lectures and this affected their learning.

\section{Moving away from 40\% Pass Mark to 50\% Pass Mark}

In South Africa, the grading system in secondary schools until 2008 (when the Education minister implemented Outcomes Based Education or OBE curriculum) the pass mark for geography ranged at code 3 (E symbol) which is between 40 - 49\% (DBE, 2016). Wilton and Erwin (2015: 12) argues that learners in South African schools are not capacitated to compete internationally due to their pass mark in schools. As articulated in Kolb (1984: 8)'s theory teaching in South Africa is pitched at the assimilating learning style which does not promote critical engagement. When learners join universities they are expected to engage in deep learning and they are also expected to obtain 50\% and above in order to pass. The study has revealed that students are unable to cope with such a transition and as a result they fail in their first year of study at university.

\section{Experiences of Geography First-year Students}

When geography first-year students were interviewed they raised several issues indicating how they struggled with their first year of study. Some students mentioned that:

At university lecturers are not teaching us the same way we were taught in secondary schools. Our teachers in secondary schools teach us until we understand, while at the university some of the issues we are expected to go out and search by ourselves and make sense of the document

This sort of transition in teaching strategy clearly presents a challenge, especially for first-year students. In this study it was found that most students were still comfortable with the traditional approach that was used in schools. But at university, students are expected to take ownership of their learning, starting from their first year of study. Dube (2012: 16) confirms that students who take ownership of their learning are likely to succeed in their studies. 
Geography first-year students struggled to cope with a teaching strategy that affected their performance.

It was also found that some of the curriculum taught at universities does not correspond with what was taught in secondary schools. One student mentioned that:

Some of the content taught was new to us. For example the content of Geographical Information System was just new to me because at secondary school we were just given background without being deep into what transpired in GIS.

Reflecting on this quotation, one can argue that there is no communication between secondary schools and universities when it comes to the development of curriculum (Dube 2012: 12). It is in part this poor communication that opens up an articulation gap which affects students' learning in their first year of study. Wilton (2012: 09) mentions the importance of consultation during curriculum development. There is a need for alignment of curriculum with regard to what is taught in secondary schools and universities when preparing student teachers to become geography teachers. Due to the lack of resources in secondary schools, some of the equipment at the university was unfamiliar to students, who as a result were unable to use it.

\section{Lecturers' Views on the Preparedness of Geography First- year Students}

When lecturers were interviewed to give their views about the level of preparedness of geography students in their first year, they responded with mixed feelings that evinced both frustration and blaming of the system. When students are admitted for the BEd programme they are expected to exit the system at NQF level eight, which includes knowledge demonstration and engagement; knowledge literacy with regard to interrogating multiple sources of knowledge; problem solving and accountability. However, in this study it was found that geography first-year students are unable to operate at this level because of the absence of continuity between school and university. One lecturer mentioned that:

These students are not ready to be at the university. Some of the stu- 
dents cannot even utter a word in English and as results they are unable to participate in class, write essays or make an argument for that matter.

Reflecting on above quotation, the issue of language and literacy takes centre stage when it comes to the preparedness of learners for university education (Dube 2012: 09). Sidiropoulos (2016: 17) argues that the subject teacher should also be conscious of language and should introduce students to basic literacy within their discipline. In this study it was found that geography first-year students are not well equipped to cope with university education. It appears that what we have called the articulation gap is simultaneously also an articulacy in English gap.

\section{Conclusion}

The study has concluded that there is no alignment between the geography secondary school curriculum and the university curriculum. The study has also concluded that even though learners pass geography well in Matric they still struggle with the first year at university due to the articulation gap between basic education teaching and higher education. The study also concludes that this gap results in challenges when it comes to student's learning. Lecturers in the geography first-year class also experience some challenges when it comes to teaching students at this level, and believe that the problem is also one of language, or an articulacy gap.

\section{Recommendation}

- There should be alignment of the geography high school and university curricula.

- The university should have a literacy course that is aligned to geography education.

- The university should consult with schools about current geography trends in the subject.

- The university and schools should exchange programmes, exchanging geography university lecturers with school teachers to strengthen the collaboration. 
Khashane Stephen Malatji \& Rachael Jesika Singh

\section{References}

Biggs, J.B. 2000. Enhancing Teaching through Constructive Alignment. Higher Education, 32, 5: 1 - 18.

Blonde, K.L. 2014. A Values Perspective on School-Based Management: School-Based Management and School Effectiveness. London: Routledge.

Creswell, T. 2007. The Teacher as Self-observer. In Richards, J.C. (ed.): The

Language Teaching Matrix. New York. Thompson Publishers.

Department of Basic Education 2016. Geography Assessment Standards.

Pretoria: Government Publications.

Department of Basic Education 2015. Geography Curriculum Development.

Pretoria: Government Publications

Department of Higher Education 2000. Blue Paper on Higher Education.

Pretoria: Government Publications.

De Vos, A.S., C.B. Strydom \& C.S.L. Delport 2013. Research at Grassroots. $4^{\text {th }}$ Edition. Cape Town: Van Schaik.

Dube, J. 2012. A Case for Improving Teaching and Learning in South African Higher Education. Higher Education Monitor No. 6. Pretoria: Council on Higher Education.

Jucu, I.S. 2012. Rethinking Geography in Romanian Schools: Curricular Changes in Geography Learning in Post-socialist Romania. Social and Behavioural Sciences, 46,20: 5440 - 5448.

https://doi.org/10.1016/j.sbspro.2012.06.454

Johnson, E. 2017. Development and Next Generation in Education. $2^{\text {nd }}$ Edition. Washington: World Bank.

Harris, L.R. \& G.T.L. Brown 2013. Opportunities and Obstacles to Consider when Using Peer- and Self-assessment to Improve Student Learning: Journal of Communications, 4,36: 101 - 111.

Heywood, J. 2000. Assessment in Higher Education: Student Learning, Teaching Programmes and Institutions. United Kingdom: Jessica Kingsley Publishers.

Kolb, J. 1974. Research Methodology. Basic Concepts in the Methodology of the Social Sciences Research. $3^{\text {rd }}$ Edition. London: Blackwell Publisher. Leedy, G. 2001. Understanding Reflective Models. $2^{\text {nd }}$ Edition. Pretoria: Van Schaik.

Malatji, K.S. \& N. Wadesango 2014. Self-reflection as a Tool to Improve 
The Articulation Gap between Learners in Secondary Schools and University

Teaching Practice: The Practice and the Timing of Self-reflection by

Primary School Teachers in the Mankweng Circuit, Capricorn District. Journal of Social Sciences 41,3: 375 - 383.

Mangena, J.P. 2017. Opportunities and Obstacles to Consider when Using

Peer- and Self-assessment to Improve Student Learning. Journal of

Communications 4,36: 101 - 111.

Mashele, P. 2016. Teaching Reflective Practice: Implementation in the Teacher-Education Setting. Journal of Teacher Education 10,48: 73 - 85. Martins, R. 2012. The National Curriculum for Basic Education in Portugal:

Theory and Practices by Geography Teachers. Social and Behavioural

Sciences 41,20: 1643 - 1647.

https://doi.org/10.1016/j.sbspro.2012.06.877

McLafferty, L. 2007. Key Methods in Geography, Los Angeles: Sage Publications.

Meristo, H. \& L. Eisenschmidt 2014. Lifelong Learning as a Goal - Do Autonomy and Self-regulation in Schools Result in Well-prepared Pupils?

Learning and Instruction. South African Journal of Higher Education 8,22: 27 - 36 .

Morrison, G.R., S.M. Ross., H.K. Kalman \& J.E. Kemp 2011. Designing Effective Instruction. $6^{\text {th }}$ Edition. London: John Wiley \& Sons Inc.

Mutshaeni, N.M. 2015. Student Access and Success: Issues and Interventions in South African Universities. Pretoria: The South African Institute for Advancement.

Pichana, S. 2017. Creating Sate and Effective Classroom. $1^{\text {st }}$ Edition. Pretoria: Van Schaik Publishers.

Psifidou, I. 2009. Innovation in School Curriculum: The Shift to Learning Outcomes. Procedia. Social and Behavioral Sciences 1, 11: 2436 - 2440. https://doi.org/10.1016/j.sbspro.2009.01.429

Rahimi, A., S.A.M. Borujeni \& M.J. Esfahany 2011. Curriculum Mapping: A Strategy for Effective Participation of Faculty Members in Curriculum

Development. Social and Behavioral Sciences 9,10: 2069 - 2073.

Salimi, L. \& A. Ghonoodi 2011. The Study and Comparison of Curriculum in Smart and Traditional Schools. Social and Behavioral Sciences 15,11: $3059-3062$.

https://doi.org/10.1016/j.sbspro.2011.04.245

Scharam, K. 2006. Reach them to Teach Them. Educational Leadership 62,7: $8-15$. 
Sediropoulos, B. 2016. Taking Health Geography Out of the Academy: Measuring Academic Impact. Social Science \& Medicine 168,16:265 272.

Shortt, H. 2016. The Culturally Proficient School: An Implementation Guide for School Leaders. Pretoria: Van Schaik.

Sikhwari, T.D. \& K.S. Malatji 2017. Problem-based Learning (PBL) as a Teaching Method in the Health Sciences: An Attempt to Review the Research Area. Journal of Educational Studies 6,2: 204 - 216.

Spaull, P. 2016. Give Encouragement for Reflection, not Praise. Texas Child Care 21,2: 3 - 11 .

Swanson, L. 2013. Better Teaching in Secondary Schools. New York: Macmillan.

Thomas, R.J. 2011. What Works in Schools: Translating Research into Action. Alexandria: Association for Supervision \& Curriculum Development.

Wilton, J. \& D.R. Erwin 2015. Interpretations of Criteria-based Assessment and Grading in Higher Education. London: Taylor \& Francis.

Wilton, L. 2012. An Alternative High School Offers Lessons on Respect. Educational Leadership 62,7: 78 - 80.

Khashane Stephen Malatji Department of Primary Education School of Education Tshwane University of Technology Soshanguve North Campus MalatjiKS@tut.ac.za

Rachael Jesika Singh Deputy Vice-Chancellor: Research Innovation and Partnerships University of Limpopo Turfloop jesika.singh@ul.ac.za 